\title{
Boxing with the past
}

Bonnie Salomon, MD

Neurology ${ }^{\circledR}$ 2018;91:1018-1019. doi:10.1212/WNL.0000000000006581
Correspondence

Dr. Salomon

bonsalomon@aol.com

MORE ONLINE

ค Audio

Listen to Dr. Salomon read this story.

NPub.org/4cg6bc

Allow a confession from this emergency physician who has treated countless patients with head injuries through the years: I love boxing. To be more precise, I loved a boxer, and that love overflowed to a romance with the so-called "sweet science." How can I reconcile my abhorrence at the damage boxing causes to the brain, so well-documented and studied, with my fondness for this kind of blood sport? This cognitive dissonance can be traced back quite easily. My father was a boxer (figure), and I was raised hearing stories about how boxing saved his life.

Boxing more commonly is thought to destroy lives, as it destroys minds, turning young men (and recently women) "punch drunk," with signs of traumatic encephalopathy. Yet my family story is different. My father was born in Poland in 1918. His older brother introduced him to boxing when he was a teen, taking him to a local gymnasium. He took to the sport, boxing with his town's "Maccabi" club, Jewish athletic clubs that flourished in 1930s Poland. He even got a match with the Polish champion and swore he would have made the Olympics had World War II not broken out in 1939. So how could boxing save the life of a young Jewish fighter?

The family lore goes something like this: as a concentration camp prisoner at Buchenwald, my father was called before the camp commandant after he allegedly threw a punch at an SS guard. The guard had hit my father's brother, and my father claimed he only threw one punch at the guard. How could it only be one punch? the commandant demanded. He said the guard's face was a mess. My father told him he was a boxer. Apparently, the commandant then recognized him, said he actually had seen my father box before the war. Instead of condemning him to be hanged, the commandant changed his mind. "As a sportsman to a sportsman, I'll let you live," he said, according to the story my father told many times.

The SS set up boxing matches for him versus guards in the camp. If he won, my father would get some extra food, some soup, perhaps some bread. This precious extra nutrition kept him going. If he could, he said he would try to share some of the food "with the other boys," as he would say. In his first match, afraid to punch a Nazi guard, he danced around the ring, until the commandant told him not to be afraid, and go ahead and fight. Fight he did. Somehow mustering the strength to box in Buchenwald, my father survived.

After hearing those stories through childhood, I could not help but associate boxing with my father, and with a sense of triumph. Unlike many Holocaust survivors who preferred not to discuss their wartime horrors with their children, my father recalled these stories with gusto, proud of his victories against all odds. He survived, thanks to his guile and his fists, or so his retelling seemed to say. He was more of an action figure than a tragic victim of history. Boxing conveyed a joy in overcoming the overwhelming. When I look at a boxing ring, I cannot help but think that in this arena, one man somehow survived, allowing his future family to endure and thrive as well. 
Figure The author's father, from an undated photograph

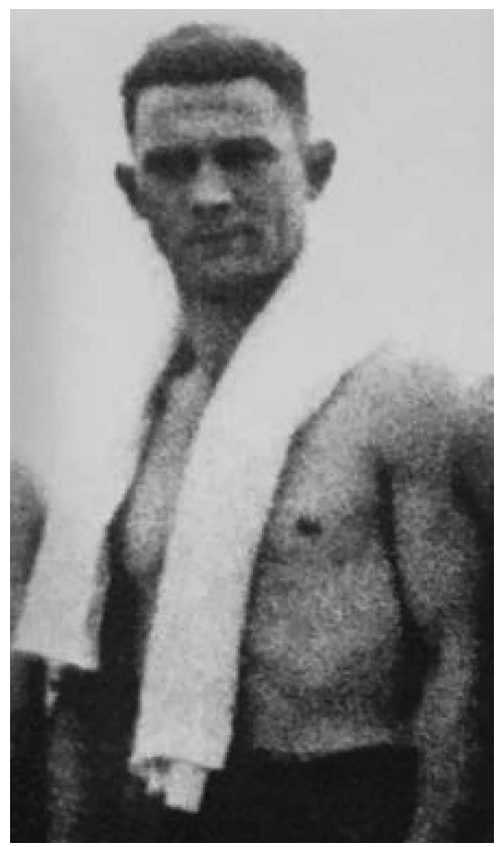

There is an artistry in the sport. There is technique, skill, and grace. Watching boxing matches on TV with my father, I was privileged to hear his expert analysis of the fighters, coming to appreciate why this fighter was going to get knocked out, or why this fighter was going to win. I learned longer reaches, longer arms, were a definite advantage. I learned about the greats, about Rocky Marciano and Muhammad Ali, about why one fighter was going to the body too often. Boxing was a shared experience for us. Boxers were heroes in my house, and my father was my personal favorite.

Now fast forward to my medical practice, seeing one concussion after another, seeing the toll they take on the cognition and personality of those patients. CT scan after scan ordered, reviewed, MRIs ordered and reviewed, neurologic exams performed and pathologies revealed. I should detest boxing. The association between boxing and traumatic brain injury has been demonstrated repeatedly. Bans on boxing are advised by medical associations. The popularity of the sport has markedly diminished since its heyday. Boxing is a niche sport now, followed by fewer fans every year. Any reasonable doctor should abhor the sport.

Perhaps this is really about hating the sin, but loving the sinner. Neurologists and other medical specialists know all too well the physical toll boxing takes on the brain. Our patients, however, are more than neuroimaging or histology. We physicians should never ignore the stories that lead our patients into this violent sport. Yes, boxing is dangerous, often brutal, and men and women should probably stop participating in it. And while boxing has been known to shatter lives, even take lives, I cannot forget, nor would I want to, the one life it did save. 


\title{
Neurology
}

\author{
Boxing with the past \\ Bonnie Salomon \\ Neurology 2018;91;1018-1019 \\ DOI 10.1212/WNL.0000000000006581
}

This information is current as of November 26, 2018

\section{Updated Information \& Services}

Citations

Subspecialty Collections

Permissions \& Licensing

Reprints including high resolution figures, can be found at: http://n.neurology.org/content/91/22/1018.full

This article has been cited by 1 HighWire-hosted articles: http://n.neurology.org/content/91/22/1018.full\#\#otherarticles

This article, along with others on similar topics, appears in the following collection(s):

\section{Brain trauma}

http://n.neurology.org/cgi/collection/brain_trauma

Information about reproducing this article in parts (figures,tables) or in its entirety can be found online at:

http://www.neurology.org/about/about_the_journal\#permissions

Information about ordering reprints can be found online:

http://n.neurology.org/subscribers/advertise

Neurology ${ }^{\circledR}$ is the official journal of the American Academy of Neurology. Published continuously since 1951, it is now a weekly with 48 issues per year. Copyright @ 2018 American Academy of Neurology. All rights reserved. Print ISSN: 0028-3878. Online ISSN: 1526-632X.

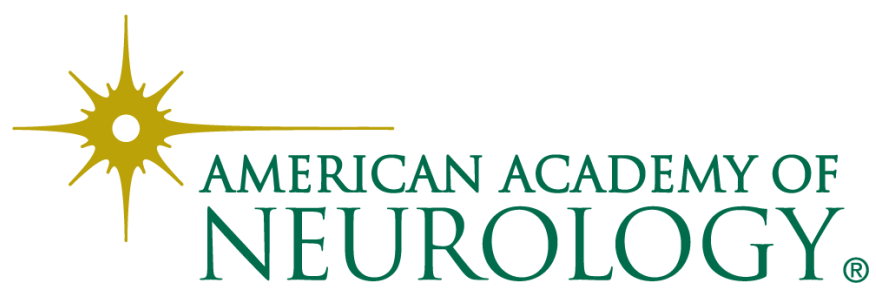

